\title{
VIRUCIDAL PROPERTIES OF INNOVATIVE DISINFECTANT TO AVIAN INFLUENZA VIRUS AND NEWCASTLE DISEASE VIRUS
}

\author{
Stegniy B. T. ${ }^{1}$, Paliy A. P. ${ }^{1}$, Pavlichenko O. V. ${ }^{2}$, Muzyka D. V. ${ }^{1}$, Tkachenko S. V. ${ }^{1}$, Usova L. P. ${ }^{1}$ \\ ${ }^{1}$ National Scientific Center 'Institute of Experimental and Clinical \\ Veterinary Medicine', Kharkiv, Ukraine, e-mail: paliy.dok@gmail.com \\ ${ }^{2}$ Kharkiv State Zooveterinary Academy, Kharkiv, Ukraine
}

\begin{abstract}
Summary. The first and the main link in the system of prevention of the occurrence and distribution of avian influenza and Newcastle disease is monitoring and the effective prophylaxis of the above diseases. At the same time the conducting of disinfection of the objects of veterinary control is an important stage in the system of veterinary and sanitary measures. A number of disinfectants that contain different classes of chemical compounds as active substances have been developed and proposed for practical use. The large-scale production of disinfectants and their introduction into practice is impossible without the preliminary laboratory assessment of their antimicrobial properties, the determination of the spectrum of their biocidal effect and physical, chemical and toxicological properties. The aim of our work was to study the virucidal properties of a new aldehyde disinfectant using the test models of the viruses of Newcastle disease and avian influenza. The experiments to study virucidal properties of the disinfectant regarding the viruses of avian influenza and Newcastle disease have been carried out at the Department for Avian Diseases Study of the National Scientific Center 'Institute of Experimental and Clinical Veterinary Medicine' in accordance with the guidelines 'Methods for determining and evaluating the safety and quality of disinfectants and disinfecting detergents used in the production, storage, transportation and sale of products of animal origin' (Kotsiumbas et al., 2010). The determination of the virucidal properties of the disinfectant has been conducted in two stages: stage $1-$ the determination of the virucidal activity of the product by the suspension method; stage 2 - determination of the virucidal activity of the product on test objects. As a result of the research conducted by the suspension method the presence of the virucidal properties of the innovative disinfectant (the mixture of quaternary ammonium compounds $-25 \%$, glutar aldehyde $-11 \%$, isopropanol, non-ionic surfactants) for the viruses of avian influenza and Newcastle disease has been determined. It has been found that the above preparation completely inactivated the infective properties of viruses when used in the concentration of $0.1 \%$, with the interval of 30 minutes and in the concentration of $0.5 \%-15$-minute interval. It has been proved that the use of the disinfectant in $0.1 \%$ concentration for 30 minutes disinfected the test objects (wood, metal, tile, textile) that were contaminated by the pathogenic agents of avian influenza and Newcastle disease
\end{abstract}

Keywords: disinfectant, virus, virucidal properties, test object, chick embryos, concentration, exposition

Introduction. At present infectious diseases of viral etiology are of great danger for industrial poultry farming. The above diseases can affect the susceptible animals and the infection can spread over the large territory very quickly. Newcastle disease (ND) and avian influenza are among the most dangerous and economically important actual diseases (Capua and Marangon, 2000; Camenisch, Bandli and Hoop, 2008; Mehrabanpour et al., 2011).

It has been known that Newcastle disease is not dangerous for human health but it is of great epizootological importance for poultry farming. In spite of the fact that the disease has been known for a long time, and the main peculiarities of its agent and pathogenesis have been studied very well, and the methods of the disease diagnosis and specific prevention have also been developed, the outbreaks of the disease are regularly registered in different countries of the world and they bring great economic losses to the farms (Liu et al., 2008; Hoque et al., 2012).

Avian influenza also causes great economic losses to poultry farming both in the developed countries and in the developing ones. Much attention in the world is paid to influenza viruses of type $A$ because the most dangerous and highly pathogenic viruses belong to this type (Capua et al., 2000; Abolnik et al., 2009).

As a result of the analysis of the present epizootic situation regarding highly pathogenic avian influenza and the risks for poultry farming in Ukraine it has been stated that avian influenza and its highly pathogenic variants pose a real threat for the industrial and private poultry farming with serious economic consequences in case of the pathogen occurrence in the farm (Stegniy, Muzyka and Pishchanskyi, 2018).

The first and the main link in the system of prevention of the occurrence and distribution of avian influenza and Newcastle disease is the monitoring and the effective prophylaxis of the above diseases. At the same time, the disinfection of the objects of veterinary control is an important stage in the system of veterinary and sanitary measures (Paliy et al., 2018; Paliy and Stegniy, 2018).

A number of disinfectants that contain different classes of chemical compounds as active substances have been developed and proposed for practical use, and they are recommended for use in different branches of industry (Zavgorodniy and Paliy, 2014; Paliy et al., 2015; Kovalenko, Paliy and Zagrebelniy, 2017; Rodionova and Paliy, 2017). 
It should be pointed out that the large-scale production of disinfectants and their introduction into practice is impossible without the preliminary laboratory assessment of their antimicrobial properties, the determination of the spectrum of their biocidal effect and physical, chemical and toxicological properties (Zavgorodniy et al., 2013; Paliy et al., 2016).

The aim of our work was to study the virucidal properties of a new aldehyde disinfectant on the test models of the viruses of Newcastle disease and avian influenza.

Materials and methods. The experiments to study virucidal properties of the disinfectant regarding the viruses of avian influenza and Newcastle disease have been carried out at the Department for Avian Diseases Study of the National Scientific Center 'Institute of Experimental and Clinical Veterinary Medicine' in accordance with the guidelines 'Methods for determining and evaluating the safety and quality of disinfectants and disinfecting detergents used in the production, storage, transportation and sale of products of animal origin' (Kotsiumbas et al., 2010). The determination of the virucidal properties of the disinfectant has been conducted in two stages: stage $1-$ the determination of the virucidal activity of the product by the suspension method; stage 2 - the determination of the virucidal activity of the product on test objects.

The preparation of the following composition was used as the tested disinfectant: the mixture of quaternary ammonium compounds $-25 \%$, glutar aldehyde $-11 \%$, isopropanol, non-ionic surfactants.

The following viruses were used as a model to study the virucidal properties of the disinfectant:

- the epizootic virus of influenza $\mathrm{A} /$ chirianka/ Dzhankoy/4-17-11/10 (H5N2) that was isolated from wild birds in the AR Crimea in 2010 by the staff of the National Scientific Center 'Institute of Experimental and Clinical Veterinary Medicine'. When infecting chicken embryos (CE), the $1.78 \mathrm{lg} \mathrm{ELD}_{50} / 0.2 \mathrm{~cm}^{3}$ was lethal. The virus $\mathrm{A} /$ chirianka/Dzhankoy/4-17-11/10 (H5N2) was deposited in the State Scientific and Control Institute of Biotechnology and Strains of Microorganisms (Kyiv), registration No. 383. The patent of Ukraine for the useful model No. 80546 was received for the virus A/chirianka/ Dzhankoy/4-17-11/10 (H5N2). The extraembryonic liquid of the chicken embryos infected by the virus A/chirianka/Dzhankoy/4-17-11/10 (H5N2) was used as virus-containing liquid. The infective activity of the virus was $6.5 \lg \mathrm{EID}_{50} / 0.2 \mathrm{~cm}^{3}$, the titer of hemaglutinins was 1:512-1:1,024;

- the epizootic virus of Newcastle disease APMV-1/ Pigeon/Doneck/3/2007 that was isolated from the wild birds in Donetsk in 2007 by the staff of the National Scientific Center 'Institute of Experimental and Clinical Veterinary Medicine. The extraembryonic liquid of the chicken embryos infected by the virus APMV-1/Pigeon/
Doneck/3/2007 was used as virus-containing liquid. The titer of hemaglutinins was 1:1,024-1:2,048.

9-10-day-old chicken embryos received from the hens having no antibodies to the viruses of Newcastle disease and avian influenza were used as a biological system for the virus indication. The incubation of the chicken embryos after the infection was carried out at the temperature $37.0 \pm 0.5^{\circ} \mathrm{C}$ for 5 days.

The egg candling was conducted daily, twice a day. The recording was done if there had been the embryo mortality and the presence of hemaglutinin in the extraembryonic liquid that testified about the reproduction of Newcastle disease and avian influenza viruses in the embryos. The dead embryos as well as alive ones after 5 days of incubation were placed in the fridge at the temperature of $4-8^{\circ} \mathrm{C}$ for $12-18$ hours and after that the autopsy was conducted. The extraembryonic liquid was taken from each embryo, the liquid was tested to detect the presence of hemagglutinating virus in the hemaglutination test with $1 \%$ suspension of the cock erythrocytes. The hemaglutination test was conducted in the in V-shaped plates by the generally accepted method. Not less than four embryos were used in each test.

The plates made from unpainted wood, metal, tile, textile (size $5 \times 10 \mathrm{~cm}$ ) were used to determine the disinfecting properties of the product.

All the experiments with the viruses of avian influenza and Newcastle disease were carried out in accordance with biosecurity rules in laminar box of the second class of protection that excludes the pathogen entering the environment. The permission for the work with the viruses of avian influenza and Newcastle disease is ISO 17025 (Certificate No. 2H1327).

Results and discussions. The influence of the work dilutions of the disinfectant under investigation had been previously studied in connection with the fact that the chicken embryos were used as the biological systems for the detection of the viruses of avian influenza and Newcastle disease.

Since chicken embryos were used as the biological system for detecting avian influenza and Newcastle disease viruses, we have previously studied the effect on them of working dilutions of the tested disinfectant.

For that the work dilutions of the drug in the concentrations of $0.1 \%$ and $0.5 \%$ were prepared. The sterile phosphate and salt buffer ( $\mathrm{pH} 7.2-7.4)$ with antibiotics (penicillin $500 \mathrm{IU} / \mathrm{cm}^{3}$, streptomycin $500 \mathrm{mkg} / \mathrm{cm}^{3}$, nystatin $25 \mathrm{IU} / \mathrm{cm}^{3}$ ) was used for the dilution. The work dilutions of the disinfectant were administered into allantois cavity of the 9-10-day-old chicken embryos at the dose of $0.2 \mathrm{~cm}^{3}$. The observation of the embryos was conducted after the injection. The sterile phosphate and salt buffer ( $\mathrm{pH}$ 7.2-7.4) with antibiotics was administered to the chicken embryos as a control. The obtained results are shown in Table 1. 
Table 1 - Assessment of the effect of work dilution of disinfectant on chicken embryos $(n=3)$

\begin{tabular}{|c|c|c|c|c|c|c|}
\hline \multirow{2}{*}{$\begin{array}{c}\text { Work } \\
\text { dilution }\end{array}$} & \multicolumn{5}{|c|}{$\begin{array}{c}\text { Quantity of dead embryos over } \\
\text { time (hours) after infection }\end{array}$} \\
\cline { 2 - 7 } & $\mathbf{2 4}$ & $\mathbf{4 8}$ & $\mathbf{7 2}$ & $\mathbf{9 6}$ & $\mathbf{1 2 0}$ \\
\hline \multirow{4}{*}{0.1} & native & 1 & - & - & 1 & - \\
\cline { 2 - 7 } & $10^{-1}$ & - & - & - & - & - \\
\cline { 2 - 7 } & $10^{-2}$ & - & - & - & - & - \\
\cline { 2 - 7 } & $10^{-3}$ & - & - & - & - & - \\
\cline { 2 - 7 } & $10^{-4}$ & - & - & - & - & - \\
\hline \multirow{4}{*}{0.5} & native & 1 & 2 & - & - & - \\
\cline { 2 - 7 } & $10^{-1}$ & - & - & - & - & - \\
\cline { 2 - 7 } & $10^{-2}$ & - & - & - & - & - \\
\cline { 2 - 7 } & $10^{-3}$ & - & - & - & - & - \\
\cline { 2 - 7 } & $10^{-4}$ & - & - & - & - & - \\
\hline \multicolumn{2}{|c|}{ Control } & - & - & - & - & - \\
\hline
\end{tabular}

Note: '-' - no cases of death.
During the study period (5 days), the death of embryos that were introduced native working dilutions of the disinfectant was observed. After 5 days of observation, all embryos were cooled under the temperature of $4-8^{\circ} \mathrm{C}$ for 12-18 hours and sectioned. The autopsy revealed growth and development retardation in embryos injected with native working dilutions of the drug and the absence of any abnormalities in embryos which were administered the drug in dilutions of $10^{-1}$ and higher (Fig.).

The data given above have proved that the tested disinfectant in $0.5 \%$ work dilution caused death and $0.1 \%$ work dilution led to the retardation of development and death of the chicken embryos. When the preparation was used in the dilution of $10^{-1}$ and higher no deviations from the norm in the development of the embryos were detected, thus, they could be used in the further experiments as the biological system to assess the virulucudal properties of the disinfectant.
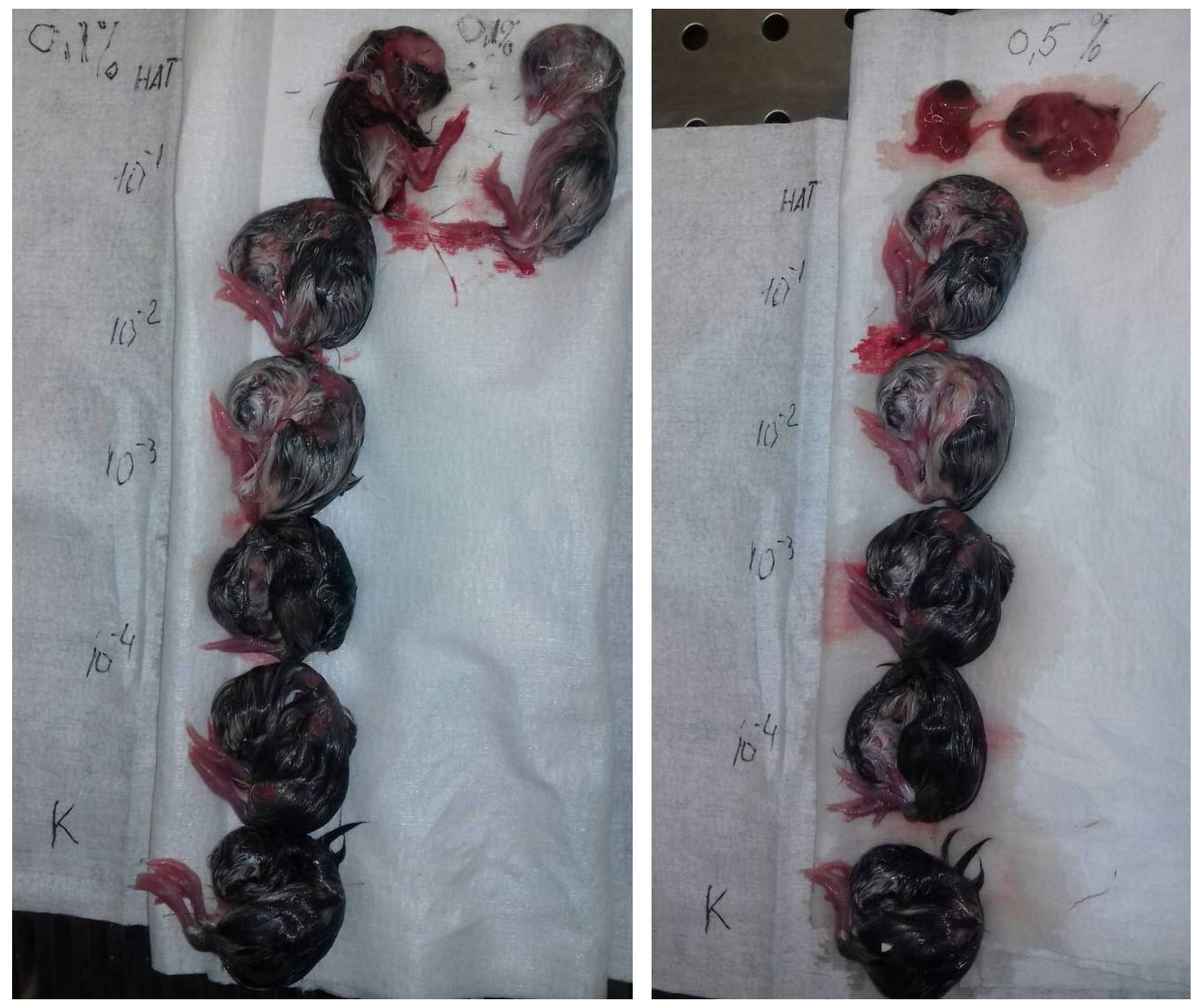

Figure. Chicken embryos after the administration of the work dilutions of the disinfectant 
During the next stage of our research the determination of the virucidal activity of the disinfectant was carried out by the suspension method. This stage consisted of the preparation of the dilutions of the tested disinfectant, the verification of the titer of infective activity of avian influenza and Newcastle disease viruses, conducting of the main experiment and controls.

0.1 and $0.5 \%$ work dilutions of the disinfectant were used for the investigation. The preparation of the work dilutions was done on the sterile phosphate and salt buffer ( $\mathrm{pH}$ 7.2-7.4) with antibiotics. The extraembryonic liquid with the viruses of Newcastle disease and highly pathogenic avian influenza was used in the dilution of $10^{-1}$. Before the beginning of the experiment the infective titer of the viruses had been checked by the titration on the chicken embryos, the titer was calculated by Reed and Mench. The infection titer of avian influenza virus was $8.75 \mathrm{lg} \mathrm{EID}_{50} / 0.2 \mathrm{~cm}^{3}$, infection titer of Newcastle disease was $6.33 \mathrm{lg} \mathrm{EID}_{50} / 0.2 \mathrm{~cm}^{3}$.

The sterile penicillin bottles with the volume of $10 \mathrm{~cm}^{3}$ were used for the experiment. The equal volumes of the extraembryonic liquid with the viruses of avian influenza and Newcastle disease in the dilution of $10^{-1}$ and the work dilutions of the disinfectant were mixed in the above bottles. The mixture was kept for 15, 30, 60, 90, 120 minutes under the room temperature. After finishing of each exposition, $1-2 \mathrm{ml}$ of the mixture were taken and used to infect the chicken embryos. Each test was accompanied by the conducting of the controls: the positive control - the virus of highly pathogenic avian influenza with sterile water in the ratio 1:1, the negative one - sterile water. The infection of the embryos was carried out in accordance with the common method using disposable syringes for that. After the infection the embryos were observed for 4-5 days with daily ovoscopy. The recording of the results of the investigation was done by the embryo death and the presence of hemagglutinin in the extraembryonic liquid of the embryos. The death during the first day with the lack of hemaglutinin was thought to be non-specific. After the end of the abovementioned period of observation all embryos that were alive were cooled and the section was conducted. The presence of viruses in the extraembryonic liquid was determined by hemaglutination test with $1 \%$ suspension of erythrocytes of the cock free from antibodies to the viruses of Newcastle disease and avian influenza (Tables 2 and 3 ).

As can be seen from Table 2, the disinfectant has virucidal properties to avian influenza virus (completely neutralizes the infectious properties of influenza virus) at concentrations not lower than $0.1 \%$ and exposure of not less than 30 minutes.

It can be seen from Table 3, that the disinfectant has virucidal properties to the virus of Newcastle disease (it completely neutralized the infective properties of the virus) when the concentration was not lower than $0.1 \%$ and the exposition was not less than 30 minutes.

After obtaining positive results in the studies by suspension method, further experiments were performed using test objects.

Thus, the investigation was carried out to determine the virucidal activity of the disinfectant on the surfaces that were contaminated by the viruses of avian influenza and Newcastle disease. For that previously cleaned, washed and sterilized test objects were used unpainted wood, metal, tile, textile with area $50 \mathrm{~cm}^{2}$.

The concentrations of the disinfectant (0.1 and $0.5 \%)$, that had shown their effectiveness at the suspension method, were used for the investigation.

Table 2 - Determination of virucidal activity of the disinfectant to avian influenza virus by the suspension method $(\mathrm{n}=4)$

\begin{tabular}{|c|c|c|c|c|}
\hline $\begin{array}{c}\text { Concentra- } \\
\text { tion of dis- } \\
\text { infectant, \% }\end{array}$ & $\begin{array}{c}\text { Expo- } \\
\text { sition, } \\
\text { min }\end{array}$ & \multicolumn{2}{|c|}{$\begin{array}{c}\text { Quantity of } \\
\text { chicken embryos }\end{array}$} & $\begin{array}{c}\text { Results of } \\
\text { hemagluti- } \\
\text { nation test }\end{array}$ \\
\hline \multirow{5}{*}{0.1} & 15 & 4 & 0 & ++-- \\
\cline { 2 - 5 } & 30 & 4 & 0 & ---- \\
\cline { 2 - 5 } & 60 & 4 & 0 & ---- \\
\cline { 2 - 5 } & 90 & 4 & 0 & ---- \\
\cline { 2 - 5 } & 120 & 4 & 0 & ---- \\
\hline \multirow{5}{*}{0.5} & 15 & 4 & 0 & ---- \\
\cline { 2 - 5 } & 30 & 4 & 0 & ---- \\
\cline { 2 - 5 } & 60 & 4 & 0 & ---- \\
\cline { 2 - 5 } & 90 & 4 & 0 & ---- \\
\cline { 2 - 5 } & 120 & 4 & 0 & ---- \\
\hline Positive control & - & 4 & 0 & ++-+ \\
\hline Negative control & - & 4 & 0 & ---- \\
\hline
\end{tabular}

Table 3 - Determination of the virucidal activity of the disinfectant to Newcastle disease virus by the suspension method $(\mathrm{n}=4)$

\begin{tabular}{|c|c|c|c|c|}
\hline $\begin{array}{c}\text { Concentra- } \\
\text { tion of dis- } \\
\text { infectant, \% }\end{array}$ & $\begin{array}{c}\text { Expo- } \\
\text { sition, } \\
\text { min }\end{array}$ & \multicolumn{2}{|c|}{$\begin{array}{c}\text { Quantity of } \\
\text { chicken embryos }\end{array}$} & $\begin{array}{c}\text { Results of } \\
\text { hemagluti- } \\
\text { nation test }\end{array}$ \\
\hline \multirow{5}{*}{0.1} & 15 & 4 & 0 & +++- \\
\cline { 2 - 5 } & 30 & 4 & 0 & ---- \\
\cline { 2 - 5 } & 60 & 4 & 0 & ---- \\
\cline { 2 - 5 } & 90 & 4 & 0 & ---- \\
\cline { 2 - 5 } & 120 & 4 & 0 & ---- \\
\hline \multirow{5}{*}{0.5} & 15 & 4 & 0 & ---- \\
\cline { 2 - 5 } & 30 & 4 & 0 & ---- \\
\cline { 2 - 5 } & 60 & 4 & 0 & ---- \\
\cline { 2 - 5 } & 90 & 4 & 0 & ++++ \\
\hline & 120 & 4 & 0 & ---- \\
\hline Positive control & - & 4 & 0 & +++- \\
\hline Negative control & - & 4 & 0 & ---- \\
\hline
\end{tabular}


The necessary amount of the virus-containing liquid was put on the clean sterile surfaces (wood, metal, tile, textile) and evenly distributed on the whole surface with the help of a glass stick. After that, the test objects were kept horizontally for 1-2 hours at the room temperature for drying. Then the surfaces were irrigated with aerosol of approximately $20 \mathrm{~cm}^{3}$ of the work solution of the disinfectant in such a way that all the surface of the test object was treated by the disinfectant. The exposition after irrigation was 30, 60, 90, and 120 minutes. After the end of each exposition the washouts from the surfaces were done by the sterile cotton swabs, then they were placed into the bottles with $1 \mathrm{~cm}^{3}$ phosphate and salt buffer for 10 minutes and then they were shaken intensively and used for the infection of the chicken embryos by the methods described above. The washouts from the contaminated surfaces treated by sterile phosphate and salt buffer were used as the positive control. Sterile phosphate and salt buffer was used as a negative control.

The test object (textile) was prepared in the following way. The sterile clean pieces of the textile were saturated by the virus-containing liquid and they were kept at the room temperature for 1-2 hours for drying. After that the textile was completely dipped in the work dilution of the disinfectant in the concentrations mentioned above and it was kept there for 30, 60, 90, and 120 minutes. After the end of the exposition the textile was taken to the sterile phosphate and salt buffer for 10 minute, it was intensively shaken and used for the infection of the chicken embryos by the methods described above. The textile saturated by the virus and dipped into the sterile phosphate and salt buffer was used as the positive control. Sterile phosphate and salt buffer was used as a negative control.

After the infection the embryos were observed for 5 days with daily ovoscopy. The recording of the results of the investigation was done by the embryo death and the presence of hemagglutinin in the extraembryonic liquid of the embryos. The death during the first day with the lack of hemaglutinin was thought to be non-specific. After the end of the above-mentioned period of observation all the embryos that were alive were cooled and the section (autopsy) was conducted. The presence of viruses in the extraembryonic liquid was determined by the hemaglutination test with $1 \%$ suspension of erythrocytes of the cock free from antibodies to the viruses of Newcastle disease and avian influenza.

The results of the virucidal effect when disinfecting the surfaces are shown in Tables 4 and 5 .

Thus, it has been found out (Table 4) that the work solution of the disinfectant in the concentrations of $0.1 \%$ and higher completely inactivated the infective properties of the viruses of avian influenza and Newcastle disease on all test objects 30 minutes after the treatment of the contaminated surface by irrigation. The viruses of avian influenza and Newcastle disease on the saturated textile were completely inactivated when dipping in the work solution of the disinfectant with the exposition of 30 minutes and more.

Table 4- Results of determination of virucidal properties of the disinfectant in $0.1 \%$ work dilution with the use of test objects $(n=3)$

\begin{tabular}{|c|c|c|c|c|}
\hline \multirow{2}{*}{$\begin{array}{c}\text { Test } \\
\text { object }\end{array}$} & \multirow{2}{*}{$\begin{array}{l}\text { Expo- } \\
\text { sition, } \\
\text { min }\end{array}$} & \multicolumn{2}{|c|}{$\begin{array}{c}\text { Quantity of chicken } \\
\text { embryos }\end{array}$} & \multirow{2}{*}{$\begin{array}{l}\text { Results of } \\
\text { hemagluti- } \\
\text { nation test }\end{array}$} \\
\hline & & infected & died & \\
\hline \multicolumn{5}{|c|}{ to avian influenza virus } \\
\hline \multirow{5}{*}{ metal } & 30 & \begin{tabular}{l|l}
3 \\
\end{tabular} & - & --- \\
\hline & 60 & 3 & - & --- \\
\hline & 90 & 3 & $1^{*}$ & --- \\
\hline & 120 & 3 & $1^{\star}$ & --- \\
\hline & control & 2 & 1 & +- \\
\hline \multirow{5}{*}{ tile } & 30 & 3 & - & --- \\
\hline & 60 & 3 & - & --- \\
\hline & 90 & 3 & - & --- \\
\hline & 120 & 3 & - & --- \\
\hline & control & 2 & $2\left(\right.$ from which $\left.1^{*}\right)$ & ++ \\
\hline \multirow{5}{*}{ textile } & 30 & 3 & - & --- \\
\hline & 60 & 3 & - & --- \\
\hline & 90 & 3 & - & --- \\
\hline & 120 & 3 & - & --- \\
\hline & control & 2 & $1^{*}$ & +- \\
\hline \multirow{5}{*}{ wood } & 30 & 3 & - & $\overline{---}$ \\
\hline & 60 & 3 & - & --- \\
\hline & 90 & 3 & - & --- \\
\hline & 120 & 3 & - & --- \\
\hline & control & 2 & $1^{\star}$ & +- \\
\hline \multicolumn{5}{|c|}{ to Newcastle disease virus } \\
\hline \multirow{5}{*}{ metal } & 30 & \begin{tabular}{|l|}
3 \\
\end{tabular} & 1 & --- \\
\hline & 60 & 3 & - & --- \\
\hline & 90 & 3 & 1 & --- \\
\hline & 120 & 3 & - & --- \\
\hline & control & 2 & 2 & ++ \\
\hline \multirow{5}{*}{ tile } & 30 & 3 & - & ---- \\
\hline & 60 & 3 & 1 & --- \\
\hline & 90 & 3 & - & --- \\
\hline & 120 & 3 & - & --- \\
\hline & control & 2 & 1 & ++ \\
\hline \multirow{5}{*}{ textile } & 30 & 3 & - & --- \\
\hline & 60 & 3 & - & --- \\
\hline & 90 & 3 & $2^{\star}$ & --- \\
\hline & 120 & 3 & - & --- \\
\hline & control & 2 & $2\left(\right.$ from which $\left.1^{\star}\right)$ & ++ \\
\hline \multirow{5}{*}{ wood } & 30 & 3 & - & --- \\
\hline & 60 & 3 & - & --- \\
\hline & 90 & 3 & 1 & --- \\
\hline & 120 & 3 & - & --- \\
\hline & control & 2 & 2 & ++ \\
\hline
\end{tabular}

Note: ${ }^{*}-$ non-specific death. 
Table 5 - Results of determination of virucidal properties of the disinfectant in $0.5 \%$ work dilution with the use of test objects $(\mathrm{n}=3)$

\begin{tabular}{|c|c|c|c|c|}
\hline \multirow{2}{*}{$\begin{array}{c}\text { Test } \\
\text { object }\end{array}$} & \multirow{2}{*}{\begin{tabular}{|c} 
Expo- \\
sition, \\
min
\end{tabular}} & \multicolumn{2}{|c|}{$\begin{array}{c}\text { Quantity of chicken } \\
\text { embryos }\end{array}$} & \multirow{2}{*}{$\begin{array}{l}\text { Results of } \\
\text { hemagluti- } \\
\text { nation test }\end{array}$} \\
\hline & & infected & died & \\
\hline \multicolumn{5}{|c|}{ to avian influenza virus } \\
\hline \multirow{5}{*}{ metal } & 30 & 3 & - & --- \\
\hline & 60 & 3 & - & --- \\
\hline & 90 & 3 & 1 & --- \\
\hline & 120 & 3 & 1 & --- \\
\hline & control & 2 & 1 & +- \\
\hline \multirow{5}{*}{ tile } & 30 & 3 & - & $\overline{---}$ \\
\hline & 60 & 3 & - & --- \\
\hline & 90 & 3 & - & --- \\
\hline & 120 & 3 & - & --- \\
\hline & control & 2 & $2\left(\right.$ from which $\left.1^{\star}\right)$ & ++ \\
\hline \multirow{5}{*}{ textile } & 30 & 3 & - & $\overline{---}$ \\
\hline & 60 & 3 & - & --- \\
\hline & 90 & 3 & - & --- \\
\hline & 120 & 3 & - & --- \\
\hline & control & 2 & $1^{*}$ & +- \\
\hline \multirow{5}{*}{ wood } & 30 & 3 & 1 & $\overline{---}$ \\
\hline & 60 & 3 & - & --- \\
\hline & 90 & 3 & - & --- \\
\hline & 120 & 3 & - & --- \\
\hline & control & 2 & $1^{*}$ & +- \\
\hline \multicolumn{5}{|c|}{ to Newcastle disease virus } \\
\hline \multirow{5}{*}{ metal } & 30 & 3 & - & --- \\
\hline & 60 & 3 & $2^{*}$ & --- \\
\hline & 90 & 3 & - & --- \\
\hline & 120 & 3 & $1^{*}$ & --- \\
\hline & control & 2 & 2 & ++ \\
\hline \multirow{5}{*}{ tile } & 30 & 3 & - & $\overline{---}$ \\
\hline & 60 & 3 & - & --- \\
\hline & 90 & 3 & $1^{*}$ & --- \\
\hline & 120 & 3 & 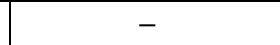 & --- \\
\hline & control & 2 & 1 & ++ \\
\hline \multirow{5}{*}{ textile } & 30 & 3 & $\overline{-}$ & --- \\
\hline & 60 & 3 & - & --- \\
\hline & 90 & 3 & - & --- \\
\hline & 120 & 3 & $1^{*}$ & --- \\
\hline & control & 2 & $2\left(\right.$ from which $\left.1^{*}\right)$ & ++ \\
\hline \multirow{5}{*}{ wood } & 30 & 3 & 1 & --- \\
\hline & 60 & 3 & - & --- \\
\hline & 90 & 3 & - & --- \\
\hline & 120 & 3 & - & --- \\
\hline & control & 2 & 2 & ++ \\
\hline
\end{tabular}

Note: ${ }^{\star}$ - non-specific death.
When testing the work dilution of the disinfectant in the concentration of $0.5 \%$ (Table 5 ) it has been proved that the above concentration caused the inactivation of the viruses on the wood, tile, metal 30 minutes after the treatment.

The textile that had been contaminated by the viruses of avian influenza and Newcastle disease was disinfected during 30 minutes when dipping in $0.5 \%$ solution of the disinfectant.

Thus, as a result of the experiments conducted by the suspension method and with the help of test objects, the parameters of disinfection by the innovative disinfectant for the surfaces made from different materials and contaminated by the viruses of avian influenza and Newcastle disease were determined (Table 6).

Table 6 - The parameters of disinfection of different objects from viral contamination by the avian influenza virus with the help of the innovative disinfectant

\begin{tabular}{|l|c|c|c|}
\hline $\begin{array}{c}\text { Surface } \\
\text { (material) }\end{array}$ & $\begin{array}{c}\text { Concentration } \\
\text { (not less than), } \\
\mathbf{\%}\end{array}$ & $\begin{array}{c}\text { Exposition } \\
\text { (not less than), } \\
\text { min }\end{array}$ & $\begin{array}{c}\text { Disin- } \\
\text { fection } \\
\text { method }\end{array}$ \\
\hline metal & 0.1 & 30 & irrigation \\
\hline tile & 0.1 & 30 & irrigation \\
\hline wood & 0.1 & 30 & irrigation \\
\hline textile & 0.1 & 30 & dipping \\
\hline
\end{tabular}

The results of the conducted research give the possibility to increase the arsenal of disinfectants that have high virucidal properties to the pathogens of the main infectious diseases of poultry.

Conclusions. The virucidal properties of the innovative disinfectant (the mixture of quaternary ammonium compounds $-25 \%$, glutar aldehyde $-11 \%$, isopropanol, non-ionic surfactants) to the viruses of avian influenza and Newcastle disease have been determined by the suspension method. It has been found that the above preparation completely inactivated the infective properties of the viruses when used in the concentration of $0.1 \%$, with the interval of 30 minutes and in the concentration of $0.5 \%$ - with the interval of 15 minutes.

The preparation disinfected the test objects (wood, metal, tile, textile) that were contaminated by the pathogenic agents of avian influenza and Newcastle disease in the concentration of $0.1 \%$, the exposition of 30 minutes.

The above disinfectant can be used for conducting the preventive and urgent disinfection of the facilities in the poultry farms taking into consideration the parameters given above. 


\section{References}

Abolnik, C., Londt, B. Z., Manvell, R. J., Shell, W., Banks, J., Gerdes, G. H., Akol, G. and Brown, I. H. (2009) 'Characterisation of a Highly pathogenic influenza A virus of subtype H5N2 isolated from ostriches in South Africa in 2004, Influenza and Other Respiratory Viruses, 3(2), pp.63-68. doi: 10.1111/j.1750-2659.2009.00074.x.

Camenisch, G., Bandli, R. and Hoop, R. (2008) 'Monitoring of wild birds for Newcastle disease virus in Switzerland using real time RT-PCR', Journal of Wildlife Diseases, 44(3), pp. 772776. doi: 10.7589/0090-3558-44.3.772.

Capua, I. and Marangon, S. (2000) 'The Avian influenza epidemic in Italy, 1999-2000: A review', Avian Pathology, 29(4), pp. 289-294. doi: 10.1080/03079450050118403.

Capua, I., Mutinelli, F., Marangon, S. and Alexander, D. J. (2000) 'H7N1 avian influenza in Italy (1999 to 2000) in intensively reared chickens and turkeys', Avian Pathology, 29(6), pp. 537-543. doi: 10.1080/03079450020016779.

Hoque, M. A., Burgess, G. W., Karo-Karo, D., Cheam, A. L. and Skerratt, L. F. (2012) 'Monitoring of wild birds for Newcastle disease virus in north Queensland, Australia', Preventive Veterinary Medicine, 103(1), pp.49-62. doi: 10.1016/j.prevet med.2011.08.013.

Kotsiumbas, I. Ya., $\quad$ Serhiienko, O. I., Kovalchyk, L. M., Tishyn, O. L., Velychko, V. O., Chaikovska, L. I., Khomiak, R. V., Kopiichuk, H. T., $\quad$ Kruzhel, N. P., $\quad$ Malynivskyi, V. M., Krushelnytska, N. V., Starchevskyi, M. K., Yakubchak, O. M., Adamenko, L. V., Kozenko, O. V., Demchuk, M. V. (2010) 'Methods for determining and evaluating the safety and quality of disinfectants and disinfecting detergents used in the production, storage, transportation and sale of products of animal origin: Guidelines' [Metody vyznachennia ta otsinky pokaznykiv bezpeky i yakosti dezinfikuiuchykh, myinodezinfikuiuchykh zasobiv, shcho zastosovuiutsia pid chas vyrobnytstva, zberihannia, transportuvannia ta realizatsii produktsii tvarynnoho pokhodzhennia: metodychni rekomendatsii], in Yakubchak, O. M. (ed.) Veterinary Disinfection (Instructions and Guidelines) [Veterynarna dezinfektsiia (instruktsiia ta metodychni rekomendatsii)]. Kyiv: Bioprom, pp. 65-148. ISBN 9789662448047. [in Ukrainian].

Kovalenko, V. L., Paliy, A. P. and Zagrebelnyi O. V. (2017) 'Study combined treatment chemicals for processing equipment and sanitary equipment for meat processing factory' [Doslidzhennia kompleksnoi dii khimichnykh rechovyn dlia sanitarnoi obrobky ustatkuvannia ta inventaria na m'iasopererobnykh pidpryiemstvakh], Veterinary Medicine [Veterynarna medytsyna], 103, pp. 38-41. Available at: http:// nbuv.gov.ua/UJRN/vetmed_2017_103_11. [in Ukrainian].

Liu, H., Wang, Z., Wu, Y., Wu, Y., Sun, C., Zheng, D., Xu, T. and Li, J. (2008) 'Molecular characterization and phylogenetic analysis of new Newcastle disease virus isolates from the mainland of China', Research in Veterinary Science, 85(3), pp. 612-616. doi: 10.1016/j.rvsc.2008.02.013.
Mehrabanpour, M. J., $\quad$ Fazel, P. D., $\quad$ Rahimian, A., Hosseini, M. H., Moein, H. and Shayanfar, M. A. (2011) 'Newcastle disease and Avian influenza A virus in migratory birds in wetland of Boushehr-Iran', International Journal of Animal and Veterinary Advances, 3(4), pp. 229-234. Available at: http://maxwellsci.com/print/ijava/v3-229-234.pdf.

Paliy, A. P. and Stegniy, B. T. (2018) 'Practical aspects of disinfection in the system of biosecurity and biosafety in veterinary medicine' [Praktychni aspekty dezinfektsii v systemi biozakhystu ta biobezpeky u veterynarnii medytsyni], Veterinary Medicine [Veterynarna medytsyna], 104, pp. 62-65. Available at: http://nbuv.gov.ua/UJRN/vetmed_2017_104_13. [in Ukrainian].

Paliy, A. P., Zavgorodniy, A. I., $\quad$ Stegniy, B. T. and Gerilovych, A. P. (2015) 'A study of the efficiency of modern domestic disinfectants in the system of TB control activities', Agricultural Science and Practice, 2(2), pp. 26-31. doi: 10.15407/ agrisp2.02.026.

Paliy, A. P., Stegniy, B. T., Muzyka, D. V., Gerilovych, A. P. and Korneykov, O. M. (2016) 'The study of the properties of the novel virucidal disinfectant', Agricultural Science and Practice, 3(3), pp. 41-47. doi: 10.15407/agrisp3.03.041.

Paliy, A. P., Ishchenko, K. V., Marchenko, M. V., Paliy, A. P. and Dubin, R. A. (2018) 'Effectiveness of aldehyde disinfectant against the causative agents of Tuberculosis in domestic animals and birds', Ukrainian Journal of Ecology, 8(1), pp. 845-850. doi: 10.15421/2018_283.

Rodionova, K. O. and Paliy, A. P. (2017) 'Analysis of quality and safety indicators of poultry meat during primary processing, Journal for Veterinary Medicine, Biotechnology and Biosafety, 3(2), pp. 5-9. Available at: http://jvmbbs.kharkov.ua/archive/ 2017/volume3/issue2/oJVMBBS_2017032_005-009.pdf.

Stegniy, B., Muzyka, D. and Pishchanskyi, O. (2018) 'Modern epizootic situation on Avian influenza in the world and Ukraine (development of domestic means of monitoring and diagnostics)' [Suchasna epizootychna sytuatsiia shchodo hrypu ptytsi u sviti ta Ukraini (rozrobka vitchyznianykh zasobiv monitorynhu, diahnostyky)], Bulletin of Agrarian Science [Visnyk ahrarnoi nauky], 11, pp. 87-92. doi: 10.31073/agrovis nyk201811-12.

Zavgorodniy, A. I. and Paliy, A. P. (2014) 'Disinfectant for protection of agricultural animals against tuberculosis' [Dezinfikuiuchyi preparat dlia zakhystu silhosptvaryn vid tuberkulozu], Agrarian Science - for Production [Ahrarna nauka - vyrobnytstvu], 1, p. 20. Available at: http://naas.gov.ua/ content/literatura/01_2014.pdf. [in Ukrainian].

Zavgorodniy, A. I., Stegniy, B. T., Paliy, A. P., Gorzheiev, V. M. and Smirnov, A. M. (2013) Scientific and Practical Aspects of Disinfection in Veterinary Medicine [Naukovi ta praktychni aspekty dezinfektsii u veterynarii]. Kharkiv: FOP Brovin O. V. ISBN 9789662445596. [in Ukrainian]. 